\title{
DIAGNOSIS OF THE NUTRIENT COMPOSITIONAL SPACE OF FRUIT CROPS ${ }^{1}$
}

\author{
LÉON-ÉTIENNE PARENT²
}

ABSTRACT - Tissue analysis is a useful tool for the nutrient management of fruit orchards. The mineral composition of diagnostic tissues expressed as nutrient concentration on a dry weight basis has long been used to assess the status of 'pure' nutrients. When nutrients are mixed and interact in plant tissues, their proportions or concentrations change relatively to each other as a result of synergism, antagonism, or neutrality, hence producing resonance within the closed space of tissue composition. Ternary diagrams and nutrient ratios are early representations of interacting nutrients in the compositional space. Dual and multiple interactions were integrated by the Diagnosis and Recommendation Integrated System (DRIS) into nutrient indexes and by Compositional Nutrient Diagnosis into centered log ratios (CND-clr). DRIS has some computational flaws such as using a dry matter index that is not a part as well as nutrient products (e.g. NxCa) instead of ratios. DRIS and CND-clr integrate all possible nutrient interactions without defining an ad hoc interactive model. They diagnose $D$ components while $D-1$ could be diagnosed in the $D$-compositional Hilbert space. The isometric log ratio (ilr) coordinates overcome these problems using orthonormal binary nutrient partitions instead of dual ratios. In this study, it is presented a nutrient interactive model as well as computation methods for DRIS and CND-clr and CND-ilr coordinates (CND-ilr) using leaf analytical data from an experimental apple orchard in Southwestern Quebec, Canada. It was computed the Aitchison and Mahalanobis distances across ilr coordinates as measures of nutrient imbalance. The effect of changing nutrient concentrations on ilr coordinates are simulated to identify the ones contributing the most to nutrient imbalance.

Index terms: Diagnosis and Recommendation Integrated System (DRIS), Compositional Nutrient Diagnosis (CND), centred log ratio (CND-clr), isometric log ratio (CND-ilr), Aitchison distance, Mahalanobis distance.

\section{DIAGNÓSE DA COMPOSIÇÃO NUTRICIONAL EM PLANTAS FRUTÍFERAS}

RESUMO - A análise do tecido é uma ferramenta útil para o manejo de nutrientes em pomares de frutas. A composição mineral dos tecidos diagnósticos expressa a concentração de nutrientes em relação à matéria seca e, tem sido muito utilizada para avaliar o status dos nutrientes "puros". Quando os nutrientes interagem nos tecidos vegetais, suas proporções ou concentrações mudam relativamente entre si, como resultado do sinergismo, do antagonismo, ou da neutralidade, produzindo, portanto, uma ressonância dentro do espaço fechado da composição do tecido. Os diagramas ternários e as relações entre nutrientes são as representações iniciais da interação de nutrientes no espaço da composição. As interações duplas e múltiplas foram integradas pelo Sistema Integrado de Diagnose e Recomendação (DRIS) nos índices de nutrientes, e pela Diagnose da Composição Nutricional nas relações do log centralizado (CND-clr). O DRIS possui algumas falhas computacionais, tais como a utilização de um índice de matéria seca o qual não faz parte, bem como os produtos de nutrientes (por exemplo, $\mathrm{NxCa}$ ) ao invés de relações. O DRIS e o CND-clr integram todas as possíveis interações de nutrientes, sem a definição de um modelo ad hoc interativo. Eles diagnosticam $D$ componentes, enquanto $D-1$ componentes podem ser diagnosticados no espaço $D$-composicional de Hilbert. As coordenadas da relação log isométrica $(\mathrm{ilr})$ supera esses problemas, usando partições de nutrientes binárias ortonormais, ao invés de relações duplas. Neste artigo, apresentamos um modelo interativo de nutrientes, bem como métodos de cálculo para DRIS, CND-clr e para as coordenadas CND-ilr (CND-ilr), utilizando dados analíticos foliares de um pomar experimental de maçã no sudoeste de Québec, no Canadá. Calculamos as distâncias de Mahalanobis e de Aitchison entre as coordenadas ilr como medidas de desequilíbrio nutricional. O efeito da alteração na concentração de nutrientes nas coordenadas ilr foi simulado para identificar aqueles que mais contribuem para o desequilíbrio de nutrientes.

Termos para indexação: Sistema Integrado de Diagnose e Recomendação (DRIS), Diagnose da Composição Nutricional (CND), relação do log centralizado (CND-clr), relação do log isométrico (CND-ilr), distância de Aitchison, distância de Mahalanobis.

'(Trabalho 049-11). Recebido em:10-01-2011. Aceito para publicação em: 11-03-2011.

2ERSAM, Département des Sols et de génie agroalimentaire, Université Laval, Québec, Canada G1V 0A6, email: leon-etienne.parent@fsaa.ulaval.ca 


\section{INTRODUCTION}

Tissue analysis is a useful tool to diagnose the nutrient status of fruit plantings (Kenworthy, 1983). There are six steps in nutrient diagnosis: (1) standardized sampling method easy to be followed by the grower, (2) routine analytical methods to extract nutrients from leaf sample, (3) standard nutrient values for diagnostic purposes, (4) interpretation of analytical results that is free of bias, (5) fertilizer recommendations to correct nutrient imbalance (shortage or excess), and (6) reports easily understood by the grower. Steps (1) and (2) are standard procedures to prepare and analyze tissue samples. Steps (5) and (6) guide fertilizer applications often based on field trials. Steps (3) and (4) are the most controversial since many diagnostic tools are based on weak assumptions and empirical computations.

Plant composition is a unique consequence of plant adaptation to a particular nutrient environment under a given set of limiting factors (Stuart-Chapin III, 1989). In crop production, Liebig's law of minimum ( $Y=k X$ up to a plateau) and Mitscherlich's law of diminishing returns $\left(\mathrm{Y}=\mathrm{A}\left[1-e^{k X}\right]\right)$ are well known response models to $X$, the growth limiting nutrient, where $Y$ is crop yield, $A$ is maximum yield, and $k$ is a proportionality constant (Trionfo, 2000). In systems analysis the ceteris paribus assumption states that all other factors but the ones being varied are equal (Giampietro, 2004). In fertilizer trials, all nutrients but the ones being varied are assumed to be plant available in sufficient but non excessive amounts and are supplemented if necessary (Nelson and Anderson, 1984). Vries (1939) showed that nutrients are interrelated in the plant system since the effect of a given nutrient on crop yield depends on how close other nutrients are from their optimum. Bayens (1967) claimed that nutrient interactions require nutrient additions to be balanced.

The critical nutrient range (CNR) approaches that related yield to nutrient concentration is commonly used to interpret plant nutrient composition as nutrient deficiency, sufficiency, luxury consumption or excess (Bates, 1971). The CNR norms are established under the assumption that other nutrients are not yield-limiting and do not interact markedly near their optimum. The CNR has been criticized for not accounting for nutrient interactions since several dual interactions have been identified in plants (Marschner, 1986; Bergmann, 1988).

According to Malavolta (2006), nutrient interactions in plants have a different meaning than statistical 2-way or higher order interactions; it is the effect of adding one element on increasing, decreas- ing or maintaining the concentration of another one as shown by foliar analysis. In statistical designs, main effect and interactions between explanatory variables can be set apart by analysis of variance while plant nutrient interactions are hidden in 'pure' nutrient values obtained from foliar analysis. Two types of bias may occur when not accounting for interactions: (1) type IV error whereby main effects are computed across interactions although the hypotheses require that interactions are examined (Umesh et al., 1996) and (2) Simpson's paradox whereby there is a disagreement in the results between separate and amalgamated sets of data (Pawlowsky-Glahn \& Egozcue, 2008). Type IV error and Simpson's paradox may lead to erroneous inferences and incorrect decisions (Umesh et al., 1996; Pawlowsky-Glahn \& Egozcue, 2008).

Resonances such as the one produced by nutrient interactions within a closed compositional space of the leaf sample generates spurious correlations and distort linear models (Aitchison, 1986). The trivial case is a 2-compositional system where the correlation coefficient between the two components is exactly -1 , i.e., any increase in one component decreases the proportion of the other by exactly the same value (Thomas \& Aitchison, 2006). Since compositional data are not free to move freely between $-\infty$ and $+\infty$, an important and useful probability distribution for such data is the logistic-normal rather than the normal distribution (Aitchison 1982, 1986). Holland (1966) suggested taking advantage of the principal component analysis (PCA) to integrate all nutrients into the same analysis and diagnose nutrient imbalance independently along the uncorrelated principal components. However, PCA requires a sound covariance matrix, spurious correlations remain in the data and the empirical PCA model is driven by raw data rather than an ad hoc theory.

The Diagnosis and Recommendation Integrated System (DRIS) (Beaufils, 1973) addressed nutrient interactions but important flaws still persist. The DRIS indexes are empirical and do not have a well defined covariance matrix for conducting multivariate statistical analyses. In M-DRIS (Hallmark et al., 1987), the dry matter (DM) index is used as separator between limiting and non limiting nutrients although DM is not a part of the composition. The diagnosis is conducted across all combinations of nutrient ratios without a pre-defined conceptual model facilitating the interpretation. Non-ratio expressions such as $\mathrm{NxCa}$ empirically designed to account for nutrient dilution in different directions over time (Walworth and Sumner, 1987) distort the Beaufils (1973) dual ratio balance approach since the sum of 
the nutrient indexes is no more equal to zero. Finally, DRIS is conducted across $D$ nutrient indexes while the Hilbert $D$-compositional space is limited to $(D-1)$ dimensions (Egozcue et al., 2003).

Lagatu and Maume (1935) were the first to illustrate tissue nutrient composition as values related to each other in the constrained compositional space using ternary diagrams where vertices represented nutrients in proportions varying between 0 and $100 \%$. Since any nutrient can be computed by difference between $100 \%$ and other proportions, there are $(D$ 1) Hilbert dimensions in a ternary diagram. Nutrient analytical results are compositional since the simplex is closed to $100 \%$. When determining the variation of components within the simplex, one may find confidence intervals with lower limits below 0 or upper limits above $100 \%$, a theoretical impossibility. To conduct linear statistical procedures, compositional data must be freed from their constrained ( 0 to $100 \%$ ) space using log ratio transformations (Aitchison, 1986) since the log transformation generates minus and plus values amenable to linear statistical analyses in the real $( \pm \infty)$ space.

Parent and Dafir (1992) applied compositional data analysis (Aitchison, 1986) to tissue diagnosis using the centered log ratio ( $c l r$ ) transformation in their Compositional Nutrient Diagnosis (CND-clr) approach. In contrast with DRIS, CND-clr has a well defined covariance matrix (Aitchison, 1986) and computes ratios from concentration values that are mutually exclusive, hence avoiding DM and nutrient products. Like DRIS, CND-clr is conducted on $D$ indexes and does not have a conceptual model to interpret nutrient interactions. CND-clr also considers all combinations of nutrient ratios without any underlying model to interpret interactions. Isometric log ratio (ilr) coordinates (Egozcue \& PawlowskyGlahn, 2005) based on sequential binary partitions reflecting nutrient interactions (CND-ilr) overcome those problems and facilitate the interpretation of the results.

The objective of this study is to present a nutrient interactive model underlying DRIS, CND$c l r$ and CND-ilr diagnoses as well as their respective computation methods. It will be discussed the $i l r$ concept using numerical examples with an apple (Malus domestica Borkh.) orchard dataset. The reader is referred to Walworth and Sumner (1987) and Parent et al. (2009) for applications of DRIS and CND-clr, respectively.

\section{Conceptual model of nutrient interactions}

The interactive model is an ad hoc classification scheme for nutrient essentiality and interactions. An element is essential if (1) a given plant is unable to complete its life cycle without it, (2) the function of the element can not be replaced by another one, and (3) the element is directly involved in plant metabolism (Marschner, 1986). Mineral elements that are not essential but stimulate plant growth or are essential to a limited number of species or under specific conditions are defined as beneficial. Callot et al. (1982) and Marschner (1986) classified essential mineral nutrients in most plant systems as follows:

- Essential macronutrients (measured in \%): $\mathrm{N}, \mathrm{S}, \mathrm{P}, \mathrm{Mg}, \mathrm{Ca}, \mathrm{K}, \mathrm{Cl}$;

- Essential micronutrients (measured in $\mathrm{mg}$ $\left.\mathrm{kg}^{-}\right): \mathrm{Mn}, \mathrm{Cu}, \mathrm{Zn}, \mathrm{Mo}, \mathrm{B}$;

- Beneficial nutrients (generally measured in $\mathrm{mg}$ or $\mu \mathrm{g} \mathrm{kg}^{-1}$ but occasionally in \% such as $\mathrm{Si}$ and $\mathrm{Na}$ ): $\mathrm{Si}, \mathrm{Na}, \mathrm{Co}, \mathrm{Ni}, \mathrm{Se}, \mathrm{Al}, \mathrm{I}, \mathrm{V}$.

Critical ranges of nutrient concentration are commonly reported in fruit crops (e.g. Bergmann, 1988). A particular case is $\mathrm{Cl}$ that is of great importance in the production of kiwifruits [Actmidia deliciosa (A Chev) C F Liang et A R Ferguson var. deliciosa] (Smith \& Clark, 1988). Bergmann (1988) and Malavolta (2006) also reported a large number of dual and multiple interactions among nutrients in plants as per example:

1 - N with S, P, K, Ca, Mg, Fe, Mn, Zn, and $\mathrm{Cu} ; \mathrm{NH}_{4}$ with $\mathrm{K}, \mathrm{Ca}$, and $\mathrm{Mg}$;

2 - S with N, P, Fe, Mn, Mo;

3 - P with $\mathrm{N}, \mathrm{K}, \mathrm{Ca}, \mathrm{Mg}, \mathrm{B}, \mathrm{Mo}, \mathrm{Cu}, \mathrm{Fe}, \mathrm{Mn}$, $\mathrm{Al}$, and $\mathrm{Zn}$;

$4-\mathrm{Cl}$ with $\mathrm{N}$ and $\mathrm{S}$;

5 - K with N, P, Ca, Mg, Na, B, Mn, Mo, and $\mathrm{Zn}$; and $\mathrm{Zn}$;

6-Ca with $\mathrm{N}, \mathrm{K}, \mathrm{Mg}, \mathrm{Na}, \mathrm{Cu}, \mathrm{Fe}, \mathrm{Mn}, \mathrm{Ni}$,

7 - Mg with N, P, B, Fe, Mn, Mo, Na, and Si;

8 - B with N, P, K, and $\mathrm{Ca}$;

9 - $\mathrm{Cu}$ with $\mathrm{N}, \mathrm{P}, \mathrm{K}, \mathrm{Ca}, \mathrm{Fe}, \mathrm{Mn}$, and $\mathrm{Zn}$;

10 - Fe with N, P, Ca, Mg, Cu, Mn, Co, and Zn;

11 - Zn with N, P, K, Ca, Mg, S, Na, Zn, Fe, and $\mathrm{Mn}$;

12 - Mn with N, P, K, Ca, Mg, B, Mo, Ni, and $\mathrm{Zn}$.

13 - Mo with N, P, K, S, Fe, and Mn.

Nutrient interactions can be handled using dual or multiple ratios. DRIS is a diagnostic tool relying on dual ratios. CND-clr and CND-ilr based on compositional data analysis rely on multiple ratios and binary nutrient partitions, respectively. 


\section{DRIS Computations}

In DRIS, nutrient balance is measured by functions and indices as follows for nutrients X, Y, and Z (Walworth \& Sumner, 1987):

$$
\begin{aligned}
& \text { Index } \mathrm{X}=\left[f\left(\frac{X}{Y}\right)+f\left(\frac{X}{\mathrm{Z}}\right) / n\right] \\
& \text { Index } \mathrm{Y}=\left[-f\left(\frac{X}{\mathrm{Y}}\right)+f\left(\frac{Y}{\mathrm{Z}}\right) / n\right] \\
& \text { Index } \mathrm{Z}=\left[f\left(-\frac{X}{\mathrm{Z}}\right)-f\left(\frac{Y}{\mathrm{Z}}\right) / n\right]
\end{aligned}
$$

Where $n$ is the number of DRIS functions involving the nutrient under diagnosis. The DRIS functions such as $f\left(\frac{X}{Y}\right)$ are computed from nutrient ratios in the diagnosed tissue and the corresponding ratio for a subpopulation of highly performing crops as follows:

$$
\begin{array}{ll}
f\left(\frac{X}{Y}\right)=\left(\frac{X / Y}{x / y}-1\right) 1000 / C V & \text { if } \mathrm{X} / \mathrm{Y}>\mathrm{x} / \mathrm{y} \text { or } \\
f\left(\frac{X}{Y}\right)=\left(1-\frac{x / y}{X / Y}\right) 1000 / C V & \text { if } \mathrm{X} / \mathrm{Y}<\mathrm{x} / \mathrm{y}
\end{array}
$$

Where $X / Y$ is the nutrient ratio of the specimen being diagnosed, $x / y$ is the nutrient ratio of the reference subpopulation, CV is coefficient of variation (i.e. standard deviation of $x / y$ divided by the mean) and 1000 is a factor to reduce the number of decimals. The two conditions to compute DRIS functions (Eqs. 4 and 5) were deemed necessary to maintain symmetry in computation. Eqs. 2-3 provide nutrient indexes with negative or positive values summing up to zero. The sum of DRIS indexes independent of sign is the nutrient imbalance index (NII).

The mean and coefficient of variation of each nutrient ratio for a high-yield reference subpopulation are the DRIS norms. Since the variance of dual ratios is generally higher in the low- than in the high-yielding subpopulations, the high-yielding reference subpopulation may be selected where the variance ratio between the low- and the high yielding subpopulations is greatest (Beaufils, 1973). The right expression for nutrient ratio $(\mathrm{X} / \mathrm{Y}$ or $\mathrm{Y} / \mathrm{X})$ is selected using the $\mathrm{F}$ ratio assuming that the high-yielding subpopulation has lower variance of nutrient ratios than the low-yielding one.

Several DRIS norms have been developed for fruit crops such as, per example, apple (Parent and Granger, 1989; Ribeiro Nachtigall and Dechen, 2007), 'Valencia' orange (Beverly, 1987a; Rodriguez et al., 1997; Mourão Filho, 2005), sweet cherries (Righetti et al., 1988), grapevine (Kumar et al., 2003; Sharma et al., 2005; Monteiro Terra et al., 2007), peach (Sanz et al., 1999), mango (Raghupathi et al., 2005; Hundal et al., 2005; Bhupal Raj \& Prasad Rao,
2006), and others (Mourão Filho, 2004).

DRIS has been redesigned empirically at several occasions in the 80's (Jones, 1981; Elwali \& Gascho 1984; Hallmark et al., 1987; Beverly, 1987a,b). Beverly (1987a,b) modified DRIS using the logarithmic transformation of nutrient ratios where $\log (\mathrm{X} / \mathrm{Y})=-\log (\mathrm{Y} / \mathrm{X})$, hence producing the same variance between expressions of the same nutrient ratio. The log-DRIS indexes were computed as follows:

$$
\begin{gathered}
\text { Index } X=\left[\frac{\log (\mathrm{X})-\log (\mathrm{x})}{\mathrm{S} \log (\mathrm{x})}+\frac{\log (\mathrm{Y})-\log (\mathrm{y})}{\mathrm{S} \log (\mathrm{y})}\right]+ \\
+\quad\left[\frac{\log (\mathrm{X})-\log (\mathrm{x})}{\mathrm{S} \log (\mathrm{x})}+\frac{\log (\mathrm{Z})-\log (\mathrm{z})}{\operatorname{Slog}(\mathrm{z})}\right]
\end{gathered}
$$

${ }^{S} \log (x),{ }^{S} \log (y)$, and ${ }^{S} \log (z)$ are the standard deviation of nutrients $x, y$ and $z$ in the reference subpopulation.

DRIS can be considered as an early attempt to analyze the compositional space of leaf analytical results. Recognizing that tissue analytical data form a compositional space of diagnostic value as conceptualized by Lagatu and Maume (1935), Parent and Dafir (1992) adopted the theory of compositional data analysis using $c l r$ and developed CND-clr.

\section{COMPOSITIONAL DATA ANALYSIS}

In mixtures of $D$ pure materials, absolute values of components measured before mixing turn, after mixing, to relative values where the sum of the parts is exactly 100\% (Aitchison, 1986; Massart et al. 1997). Compared to the unconstrained real space $( \pm \infty)$, the constrained compositional space is made of strictly positive data between 0 and $100 \%$. As proportions of ingredients change, proportions of other parts must change concomitantly. Resonance among changing proportions that generates spurious correlations in the compositional space distorts linear analysis as shown by PCA conducted on raw proportions where 'banana'-shape rather than ellipsoidal data distribution may occur (Aitchison, 1986).

A $D$-part composition $\mathrm{x}=\left[x_{1}, x_{2}, \ldots, x_{\mathrm{D}}\right]$ can be described by its parts $x_{1}, x_{2}, \ldots, x_{\mathrm{D}}$ as follows (Aitchison, 1986):

$$
\mathrm{x}=\mathrm{C}\left(\mathrm{x}_{1}, \mathrm{x}_{2}, \ldots, \mathrm{x}_{D}\right)=\left(\frac{x_{1} x}{\sum_{i=1}^{\mathrm{D}} x i}, \frac{x_{2} x}{\sum_{i=1}^{\mathrm{D}} x i}, \ldots, \frac{x_{D} x}{\sum_{i=1}^{\mathrm{D}} x i}\right)
$$

Where $C$ is the closure operator to unit such as weight or volume percentage or fraction, $\mathrm{g} \mathrm{kg}^{-1}$ or $\mathrm{g} \mathrm{L}^{-1}$. If tissue subcomposition is examined using a ternary diagram (e.g. Lagatu and Maume, 1935), the subcomposition is closed to $100 \%$ or 1 .

Since compositional data carry relative information, they must be ratio-transformed to express their position relative to each other in the compositional space. Log ratios are used to project compo- 
sitional data into the real space. Additive log-ratio (alr) and $c l r$ transformations have been proposed by Aitchison (1986). Natural logarithms are used for log transformations since they are the standard approach in statistics (Pawlowsky-Glahn \& Egozcue, 2006). The alr and clr values are computed as follows:alr $r_{i}$

$$
\begin{aligned}
& (x)=\ln \left(x_{i} / x_{D}\right) \\
& \operatorname{clr}_{i}(x)=\ln \left(x_{i} / g(x)\right)
\end{aligned}
$$

Where $x_{i}$ and $x_{D}$ are proportions and $g(x)$ is geometric mean across proportions. The alr has oblique geometry restricting data representation in the compositional space (Egozcue \& Pawlowsky-Glanh, 2006). The sum of $c l r_{i}(x)$ values is zero since the compositional space is constrained to $100 \%$. This is why the matrix of $c l r$ values is singular and one $c l r$ (generally the one corresponding to the filling value) is excluded when conducting multivariate analysis. Like DRIS, CND-clr classifies nutrient indexes in the order of nutrient limitation to crop performance using a magnitude with a direction (minus signs signify relative deficiency while plus signs mean relative excess). The $\mathrm{clr}$ is measured in $D$ rather than D-1 dimensions.

The $c l r$ transformation has adequate geometry to compute the Aitchison distance between compositions $x$ and $y$, the analog to Euclidian distance in the compositional space, as follows (Egozcue \& Pawlowsky-Glanh, 2006):

$$
d(x, y)=d(\operatorname{clr}(x), \operatorname{clr}(y))=\Sigma_{i=1}^{D-1}(\operatorname{clr}(y))^{2}
$$

The log ratio expressions are more intuitive than absolute values to describe changes in the compositional space when one factor varies. Different mixtures of ingredients can produce the same shifts in absolute terms without showing what changes have really occurred (Odeh et al., 2003). For a 3-part simplex, if composition changes from $[5,35,60]$ to $[10,30,60]$ in sample A, the Euclidean distance in the real space is as follows:

$$
d_{\mathrm{A}}=\sqrt{\left[(5-10)^{2}+(35-30)^{2}+(60-60)^{2}\right]}=\sqrt{50}=7.07
$$

If composition changes from $[45,35,20]$ to $[50,30,20]$ in sample $B$, the Euclidean distance is as follows:

$d_{B}=\sqrt{[35-40)^{2}+(45-40)^{2}+(20-20)^{2}}$

Although, there is more similarity upon change in sample B since the first component in sample A doubled its proportion in response to fac- tor shift.

Using $c l r$, the geometric means before and after change are $(5 \times 35 \times 60)^{1 / 3}=21.9$ and $(10 \times 30 \times 60)^{1 / 3}=26.2$ for sample $A$ and $(30 \times 45 \times 20)^{1 / 3}=$ 31.6 and $(40 \times 40 \times 20)^{1 / 3}=31.1$ for sample B. Corresponding $\mathrm{clr}$ values are $[-1.477,0.469,1.008]$ and $[-0.963,0.135,0.828]$ for sample $A$ and $[0.354$, $0.103,-0.457]$ and $[0.476,-0.035,-0.441]$ for sample B. The Aitchison distances (Eq. 3) are 0.638 in sample $A$ and 0.185 in sample $B$, confirming the evidence that change was greater in sample $A$ than in sample B.

\section{From DRIS to CND-CLR}

Assuming ${ }^{S} \log (x)={ }^{S} \log (y)={ }^{S} \log (z)$, Parent and Dafir (1992) obtained the following expression:

$$
\text { Index } X=\left[\frac{\log (X / g(X))-\log (x / g(x))}{{ }^{S} \log (x)}\right]
$$

Where $g(X)$ and $g(x)$ are the geometric means of concentrations for nutrients $\mathrm{X}, \mathrm{Y}$ and $\mathrm{Z}$ in the diagnosed specimen and the reference subpopulation, respectively, and $\log (X / g(X))$ is a log contrast between a given nutrient and the geometric mean of the composition. The selection of the high-yielding reference subpopulation was conducted across multiple ratios using a cumulative variance function fitted to cubic (Khiari et al., 2001a) or Boltzmann (Hernandez-Caraballo et al., 2008) equations. In CND-clr, the imbalance index between a given composition and a standard one can be computed as Aitchison (Egozcue \& Pawlowsky-Glahn, 2006), chi-square (Parent et al., 1994), or Mahalanobis (Parent et al., 2009) distances.

The Mahalanobis distance is computed as follows:

$\chi_{\mathrm{D}}^{2}=\sum_{\mathrm{i}=1}^{\mathrm{D}}\left(c l r_{i}-c l r_{i}^{*}\right)^{T} \mathrm{COV}^{-1}\left(c l r_{i}-c l r_{i}^{*}\right)$

Where $c l r_{i}$ is the $i^{\text {th }} c l r$ value, $\operatorname{clr}_{i}^{*}$ is the arithmetic mean, and $\mathrm{COV}^{-1}$ is the inverse covariance matrix of $c l r$ values across the high-yield subpopulation population. The chi-square distance is computed using Eq. 14 except that $\mathrm{COV}^{-1}$ is replaced by $V A R^{-1}$, the inverse variance matrix. The Aitchison distance is computed after replacing the covariance matrix by the identity matrix. In contrast with the Aitchison distance, the inverse variance and covariance matrices weight the difference $\left(c l r_{i}-c l r_{i}^{*}\right)$ by a dispersion factor.

Parent et al. (1994) found close correlations between DRIS and CND-clr. Khiari et al. (2001b) found that CND-clr values were closely related to 
DRIS indexes $\left(r^{2}=0.91-0.99\right)$ but poorly to well related to nutrient concentrations $\left(r^{2}=0.34-0.87\right)$ in sweet corn. Kumar et al. (2003) found that CND-clr had greater diagnostic power than DRIS in grapevine.

\section{Isometric log ratio transformation}

Egozcue \& Pawlowsky-Glahn (2005) proposed the isometric log-ratio (ilr) transformation for compositional data that can be arranged sequentially into binary partitions of non overlapping subcompositions. Egozcue et al. (2003) and Egozcue \& Pawlowsky-Glanh (2005) found that ordered $D$ size fractions can be combined into $(D-1)$ sequential partitions with orthonormal basis. The isometric log ratios (ilr) are proportional to the logarithm of a ratio of two geometric means of parts forming two groups (Egozcue \& Pawlowsky-Glanh, 2006).

The ilr coordinates project $D$ proportions into (D-1) orthonormal dimensions that can be arranged in a way to describe the system under study. Plant compositional data can be partitioned according to their role in the plant, mobility in the soil or nutrient management. Several important dual nutrient ratios having diagnostic significance (Marschner, 1986; Bergmann, 1988; Malavolta, 2006) can assist in constructing the ilr partitions. The difference between a given composition and a standard or reference one is computed as the Aitchison distance (Egozcue \& Pawlowsky-Glahn, 2005).

The $i^{\text {th }} i l r$ coordinate $x_{i}^{*}$ is called compositional dimension, orthonormal base, or balance between two groups of components that had been arranged sequentially. The ilr coordinate is computed as a contrast between two groups of parts with the directions plus $(+)$ (numerator) or minus $(-)$ (denominator), as follows (Egozcue \& Pawlowsky-Glahn, 2006):

$$
x_{i}^{*}=\sqrt{\frac{r s}{r+s}} \ln \frac{g\left(x_{+}\right)}{\mathrm{g}\left(x_{-}\right)},
$$

Where $r$ and $s$ are numbers of components in plus $(+)$ and minus (-) groups, respectively, $g\left(x_{+}\right)$is geometric mean of components in the plus group $x_{+}$ and $\mathrm{g}\left(x_{-}\right)$is geometric mean of components in the minus group $x_{-}$. The Aitchison distance $A$ between two compositions is computed across $i l r$ coordinates as follows (Egozcue \& Pawlowsky-Glanh, 2006):

$$
\mathrm{d}^{2}{ }_{\mathrm{a}}(x, y)=\Sigma_{i=1}^{D-1}\left(x_{i}^{*}-y_{i}^{*}\right)^{2} \text { and } A=\sqrt{\mathrm{d}^{2}(x, y)},
$$

Eq. 16 is Aitchison norm if $y_{i}^{*}$ is the neutral element assigned a value of zero. The ilr transformation has a sound covariance structure and is amenable as real data to statistical tests such as normality tests and to linear statistical analyses.

The ilr partitions are defined a priori by a conceptual interactive model elaborated from current knowledge to facilitate the interpretation of the results. A binary partition of nutrients reflecting multiple interactions is analog to a dual ratio since one or many nutrients show up in the numerator and the denominator of the ratio. For example, the dual $\mathrm{N}$ : P ratio is an important criterion for adaptation of terrestrial plants (Güsewell, 2004). Since N and P interact within a closed compositional space, other nutrients are assumed to vary to such a small extent that the N: P ratio remains within narrow limits. For a binary partition (Eq. 15) such as [N, S] vs. [P], S is assumed to be nearly constant in the protein metabolism to express the fact that the $\mathrm{N}$ : $\mathrm{P}$ ratio is the main criterion. The $\mathrm{NxCa}$ product mitigating nutrient dilution (Walworth and Sumner, 1987) appears in the binary partition between anions and cations as $[\mathrm{N}, \mathrm{S}, \mathrm{P}]$ vs. $[\mathrm{K}, \mathrm{Ca}, \mathrm{Mg}]$, where $\mathrm{S}, \mathrm{P}, \mathrm{K}$, and $\mathrm{Mg}$ are assumed to be nearly constant. The binary partitions are arranged using the best knowledge in plant physiology, soil science, and nutrient management.

Data amalgamation is frequent in compositional data analysis especially when dealing with zeroes (Martin-Fernandez et al., 2003) that can be handled by ilr coordinates. Data amalgamation has non linear behaviour (Egozcue \& Pawlowsky-Glahn, 2005). In tissue diagnosis, a form of data amalgamation is the cationic molar ratio $K /(\mathrm{Ca}+\mathrm{Mg})$ (Bergmann, 1988). Two cations are amalgamated $(\mathrm{Ca}+\mathrm{Mg})$ despite the fact that both are essential elements with contrasting roles in the plant. As a result, a fine $K$ / $(\mathrm{Ca}+\mathrm{Mg})$ molar ratio may be misinterpreted as adequate for plant growth while the $\mathrm{K} / \mathrm{Mg}$ and $\mathrm{K} / \mathrm{Ca}$ ratios are inappropriate. The following ilr coordinates avoid this paradox using two orthonormal dimensions $\left(x_{1}^{*}\right.$ and $\left.x_{2}^{*}\right)$ :

$x_{1}^{*}=\sqrt{\frac{2}{1+2}} \ln \frac{\mathrm{K}}{\sqrt{C a \times M}}$ and $x_{2}^{*}=\sqrt{\frac{1}{1}} \ln \frac{C a}{M g}$

\section{Dataset and statistical analyses}

The dataset used to compare DRIS, CND-clr, and CND-ilr and provide computation examples is derived from a fertilization study conducted by Parent and Grander (1989) on an experimental apple orchard (Malus domestica Borkh.) in southwestern Quebec, Canada. Briefly, there were 12 fertilizer treatments combined with four rootstocks ('Malling 7', 'Malling 26', 'Ottawa 3', and 'Malling 9') for 'Morspur McIntosh' scions. There was control and fertilizer treatments as follows: (1) 0,50 or $100 \mathrm{~kg}$ $\mathrm{N} \mathrm{ha}^{-1}$, (2) 0 or $24 \mathrm{~kg} \mathrm{P} \mathrm{ha}^{-1}$, (3) 0 or $75 \mathrm{~kg} \mathrm{~K} \mathrm{ha}^{-1}$, 
(4) 0 or $1380 \mathrm{~kg} \mathrm{Ca} \mathrm{ha}^{-1}$ as $\mathrm{Ca}(\mathrm{OH})_{2}+6.5 \mathrm{~kg} \mathrm{Ca}$ $\mathrm{ha}^{-1}$ as foliar application, and (5) 0 or $43 \mathrm{~kg} \mathrm{Mg} \mathrm{ha}^{-1}$ as soil-applied Epsom salt $+2.3 \mathrm{~kg} \mathrm{Mg} \mathrm{ha}^{-1}$ as foliar applied Epsom salt. In each treatment, nutrients not being varied were applied at highest rate. The dataset comprised cumulated yields and average leaf compositions.

Ten to 30 leaf samples were collected in the center of the annual growth at the end of July and analyzed for $\mathrm{N}, \mathrm{P}, \mathrm{K}, \mathrm{Ca}$, and $\mathrm{Mg}$. DRIS, CND-clr and CND-ilr were compared using nutrient imbalance indexes that included the dry matter index in DRIS and the filling value in CND-clr and CND-ilr. The DRIS NII and the CND-clr Aitchison distance associated with high yields must be small. For $i l r$, we computed the Aitchison distance (identity matrix), the chi-square value assuming independent standardized $i l r$ coordinates (variance matrix), and the Mahalanobis distance (covariance matrix).

It was formed groups of data yield using the $k$-means procedure in the $\mathrm{R}$ package to select the high-yield subpopulation. DRIS and CND computations were conducted using the Excel package. The nutrient imbalance indexes were ranked in an ascending order and the sum of squares was iterated between two groups using the Cate-Nelson procedure (Nelson and Anderson, 1984). The first peak of the sums of squares was selected to determine the critical nutrient imbalance index. The rate of success of the diagnosis was computed as the sum of true high- and low-yielders about the critical index divided by total number of observations.

\section{Selection of the interactive model and reference norms}

The ilr partitions were arranged as shown in Table 1. We selected the first balance as a general one between analytical results and the filling value computed as $1000 \mathrm{~g} \mathrm{~kg}^{-1}$ minus analytical results. The high-order binary partition contrasted nutrients with the filling value and $\mathrm{N}$ and $\mathrm{P}$ against cations. Lower-order partitions were subgroups of the main ones. The interaction between $\mathrm{N}$ and $\mathrm{P}$ is well documented (Güsewell, 2004). Cations are antagonistic (e.g. Bergmann, 1988). This choice of binary contrasts was confirmed by bi-plots of $c l r$ values for the dataset where each nutrient has a direction relative to others (data not shown).

The CND-clr indexes were computed from the mean and coefficient of variation of the 75 top yielders as defined by the $k$-means procedure $(>$ $44.7 \mathrm{~kg} \mathrm{ha}^{-1}$ over 4 years of production) (Table 2). As mentioned by Hadi $(1992,1994)$ and Filzmoser and Hron (2008), Mahalanobis distance is very sensi- tive to the choice of the location estimator (mean or median). We selected the median ilr coordinates of the whole population as location for the covariance matrix (Table 3) used to compute the Mahalanobis distances since nutrient imbalance indexes were not normally distributed due to extreme cases from properly fertilized trees to partial or complete failure among nutrient deficient trees. The $\left(i l r_{\mathrm{i}}-i l r_{i}^{*}\right)$ difference was computed using $i l r_{i}^{*}$ as the mean value in the reference subpopulation (Table 2).

\section{Correlations between dris, cnd-clr and cnd-ilr}

As expected from theory, the Aitchison distance was the same whether computed from $\mathrm{clr}$ or $i l r$ values (Fig. 1). Although DRIS NII was related to the Aitchison distance (Fig. 1), there were some discrepancies for DRIS NII values between 0 and 10 indicating some computational flaws in DRIS compared to compositional data analysis. The Mahalanobis distance computed from the covariance matrix was loosely related to Aitchison distance and closely related to the Mahalanobis distance computed from the variance matrix (Fig. 2). As a result, diagnostic success rate for the dataset must vary among approaches.

The critical values from the Cate-Nelson procedure were 3.17 for DRIS-NII, 0.085 for the Aitchison distance, 1.00 for the Mahalanobis distance computed using the covariance matrix, and 1.06 for the Mahalanobis distance computed using the variance matrix. The rate of classification success about critical values (i.ie the proportion of correctly classified observations as true high yielders plus true low yielders, with $44.7 \mathrm{Mg} \mathrm{ha}^{-1}$ as yield cutoff) was $67.3 \%$ for DRIS, $75.9 \%$ for the Aitchison distance, $74.5 \%$ for the Mahalanobis distance computed using the covariance matrix, and $73.4 \%$ for the Mahalanobis distance computed using the variance matrix. The Aitchison distance was thus used in the following computational example.

\section{Computation of the ilr coordinates AND the Aitchison distance}

Suppose that the results of leaf analysis on a dry weight basis are as follows: $2.50 \% \mathrm{~N}, 0.22 \%$ $\mathrm{P}, 2.64 \% \mathrm{~K}, 1.15 \% \mathrm{Ca}$, and $0.11 \% \mathrm{Mg}$. The filling value is $100 \%$ minus the sum of analytical results, i.e. $93.38 \%$. We computed the ilr coordinates (Eq. 13 and Table 1) as follows: 


$$
\begin{aligned}
& i l r_{1}=\sqrt{\left(\frac{5 \times 1}{5+1}\right)^{\ln }\left(\frac{(2.5 \times 0.22 \times 2.64 \times 1.15 \times 0.11)^{1 / 5}}{(93.38)^{1 / 1}}\right)=-4.451} \\
& i l r_{2}=\sqrt{\left(\frac{2 \times 3}{2+3}\right) \ln \left(\frac{(2.50 \times 0.22)^{1 / 2}}{(2.64 \times 1.15 \times 0.11)^{1 / 3}}\right)=0.073} \\
& i l r_{3}=\sqrt{\left(\frac{1 \times 1}{1+1}\right)} \ln \left(\frac{(2.50)^{1 / 1}}{(0.22)^{1 / 1}}\right)=1.719 \\
& i l r_{4}=\sqrt{\left(\frac{1 \times 2}{1+2}\right)} \ln \left(\frac{(2.64)^{1 / 2}}{(1.15 \times 0.11)^{1 / 2}}\right)=1.637 \\
& i l r_{5}=\sqrt{\left(\frac{1 \times 1}{1+1}\right)} \ln \left(\frac{(1.15)^{1 / 1}}{(0.11)^{1 / 1}}\right)=1.660
\end{aligned}
$$

The Aitchison distance was computed in the following sequence:

$$
\begin{aligned}
& i l r_{1}-i l r_{1}{ }^{*}=-4.451+4.449=-0.001 \\
& i l r_{2}-i l r^{*}=0.073+0.004=0.077 \\
& i l r_{3}-i l r_{3}{ }^{*}=1.719-1.739=0.021 \\
& i l r_{4}-i l r_{4}{ }^{*}=1.637-1.154=0.482 \\
& i l r_{5}-i l r_{5}{ }^{*}=1.661-1.057=0.613
\end{aligned}
$$

$A=\left[(-0.001)^{2}+(0.077)^{2}+(-0.021)^{2}+(0.482)^{2}+(0.613)^{2}\right]^{1 / 2}=0.776$

Since the critical value for $A$ is 0.085 , nutrient imbalance apparently limits yield. The largest imbalance occurs with $i l r_{5}$ between $\mathrm{Ca}$ and $\mathrm{Mg}$, and $i l r_{4}$ between $\mathrm{K}, \mathrm{Ca}$, and $\mathrm{Mg}$.

The mean concentration values for top yielders were as follows: $2.48 \% \mathrm{~N}, 0.21 \% \mathrm{P}, 1.89 \% \mathrm{~K}$, $0.95 \% \mathrm{Ca}$, and $0.21 \% \mathrm{Mg}$. At first glance, $\mathrm{Mg}$ was the most limiting nutrient. Setting Mg equal to $0.21 \%$

\begin{tabular}{|c|c|c|c|c|c|c|c|c|c|}
\hline & $\mathrm{N}$ & $\mathrm{P}$ & $\mathrm{K}$ & $\mathrm{Ca}$ & $\mathrm{Mg}$ & $\mathrm{Fv}^{2}$ & Interpretation & $r^{1}$ & $\mathrm{~S}$ \\
\hline 1 & 1 & 1 & 1 & 1 & 1 & -1 & Nutrients vs. filling value & 5 & 1 \\
\hline 2 & 1 & 1 & -1 & -1 & -1 & 0 & Anions vs. cations & 2 & 3 \\
\hline 3 & 1 & -1 & 0 & 0 & 0 & 0 & N vs. $\mathrm{P}$ & 1 & 1 \\
\hline 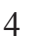 & 0 & 0 & 1 & -1 & -1 & 0 & $\mathrm{~K}$ vs. $\mathrm{Ca}+\mathrm{Mg}$ & 1 & 2 \\
\hline 5 & 0 & 0 & 0 & 1 & -1 & 0 & $\mathrm{Ca}$ vs. $\mathrm{Mg}$ & 1 & 1 \\
\hline
\end{tabular}
instead of $0.11 \%$, the Aitchison distance was 0.329 , still well above the critical value. Setting $\mathrm{K}$ equal to $1.89 \%$ and $\mathrm{Mg}$ to $0.21 \%$, the Aitchison distance was 0.168 . Setting $\mathrm{Ca}$ equal to $0.95 \%$, K to $1.89 \%$, and $\mathrm{Mg}$ to $0.21 \%$, the Aitchison distance was 0.048 . Apparently, the $\mathrm{Mg}$ fertilization should be enhanced and the $\mathrm{K}$ fertilization stopped as first step to recover from nutrient imbalance.

TABLE 1 - Sequential orthogonal partition of eleven nutrients to compute ten ilr orthonormal coordinates.

${ }^{1} \mathrm{r}=$ number of positive signs and $\mathrm{s}=$ number of negative signs

${ }^{2}$ Filling value between unit of measurement and analytical results

TABLE 2 - Nutrient norms for CND-clr and CND-ilr for the experimental apple orchard in Quebec.

\begin{tabular}{lcc}
\hline Nutrient variate & Mean & $\begin{array}{c}\text { Standard deviation } \\
\text { Clr variate }\end{array}$ \\
$\mathrm{N}$ & 0.411 & 0.053 \\
$\mathrm{P}$ & -2.040 & 0.089 \\
$\mathrm{KI}$ & 0.118 & 0.112 \\
$\mathrm{Ca}$ & -0.515 & 0.109 \\
$\mathrm{Mg}$ & -2.036 & 0.138 \\
Filling value & 4.062 & 0.042 \\
& & \\
Ilr1 & Ilr coordinates \\
Ilr2 & -4.449 & 0.046 \\
Ilr3 & -0.004 & 0.068 \\
Ilr4 & 1.739 & 0.090 \\
Ilr5 & 1.154 & 0.142 \\
\hline
\end{tabular}


TABLE 3 - Covariance and variance matrices of the ilr coordinate using the median value across the whole population as location.

\begin{tabular}{|l|c|c|c|c|c|}
\hline Coordinate & Ilr1 & Ilr2 & Ilr3 & Ilr4 & Ilr5 \\
\hline & \multicolumn{5}{|c|}{ Covariance matrix } \\
\hline Ilr1 & 599.39 & 123.33 & 121.97 & 30.50 & 32.69 \\
\hline Ilr2 & 123.33 & 266.33 & 71.37 & -39.40 & -23.63 \\
\hline Ilr3 & 121.97 & 71.37 & 162.33 & 3.20 & 12.06 \\
\hline Ilr4 & 30.50 & -39.40 & 3.20 & 52.80 & -7.91 \\
\hline Ilr5 & 32.69 & -23.63 & 12.06 & -7.91 & 28.33 \\
\hline & \multicolumn{6}{|c|}{ Variance matrix } \\
\hline Ilr1 & 599.39 & 0 & 0 & 0 & 0 \\
\hline Ilr2 & 0 & 266.33 & 0 & 0 & 0 \\
\hline Ilr3 & 0 & 0 & 162.33 & 0 & 0 \\
\hline Ilr4 & 0 & 0 & 0 & 52.80 & 0 \\
\hline Ilr5 & 0 & 0 & 0 & 0 & 28.33 \\
\hline
\end{tabular}
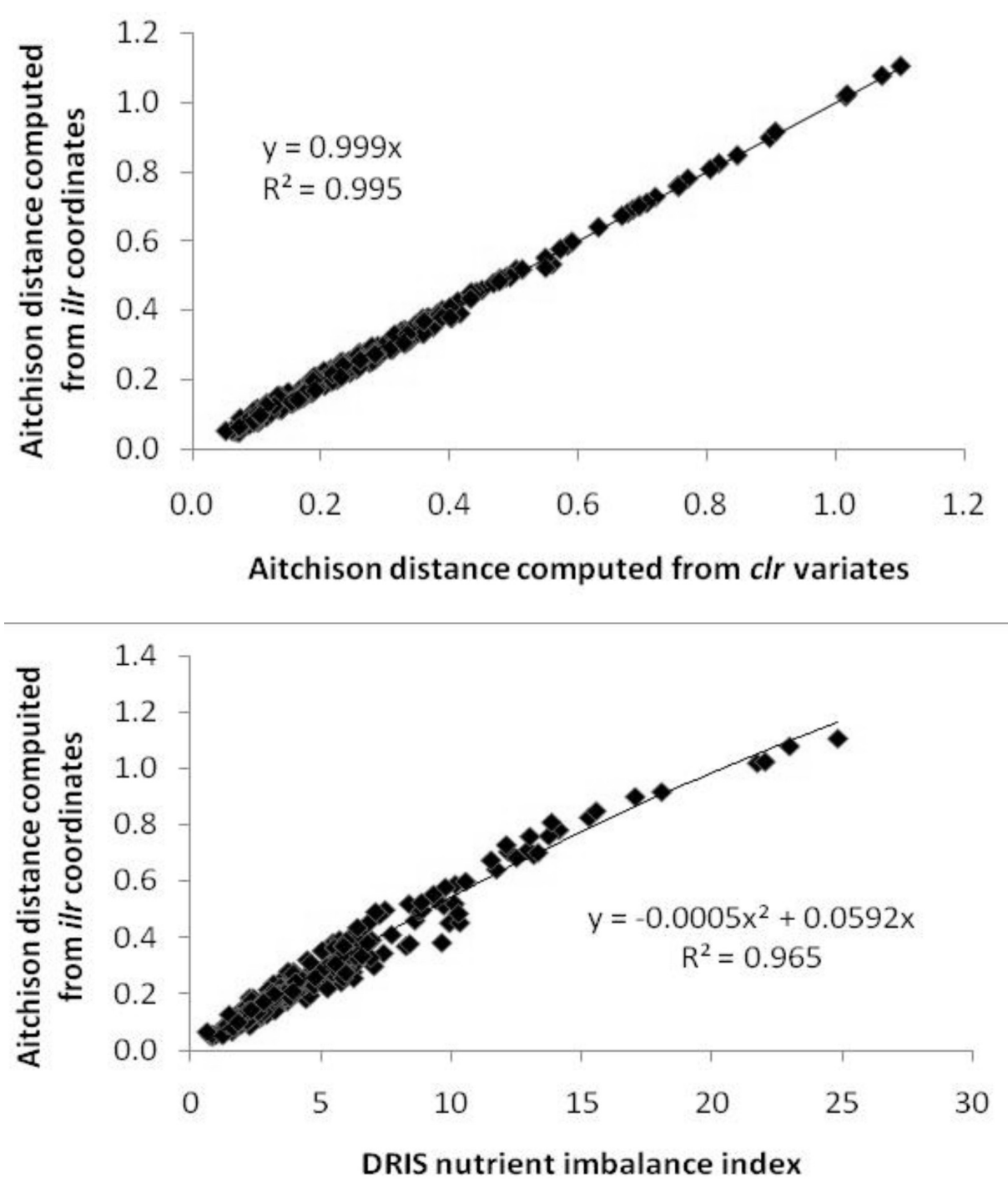

FIGURE 1 - Relationships between nutrient imbalance indexes for CND-ilr and DRIS NII. 


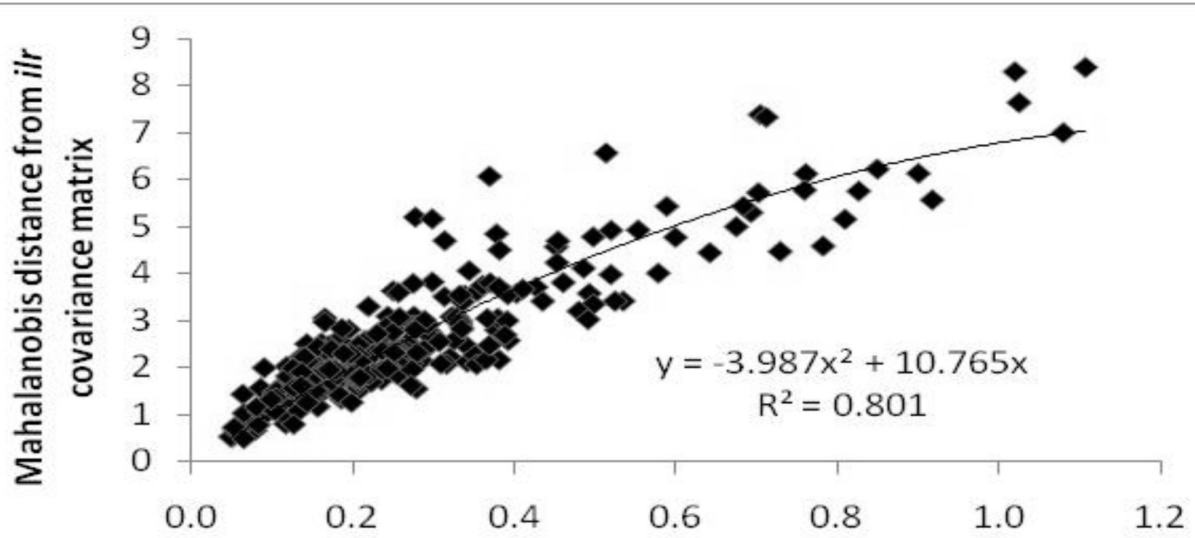

Aitchison distance using ilr coordinates

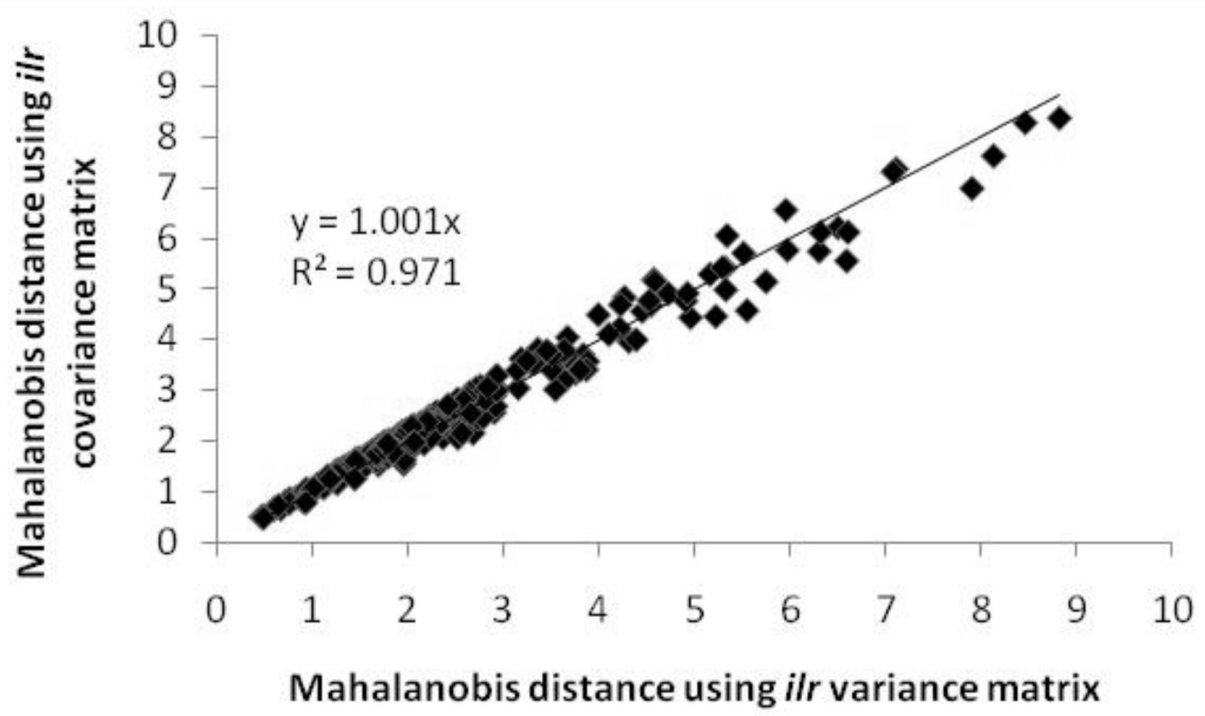

FIGURE 2 - Relationships between the Mahalanobis distance using the covariance matrix and the Aitchison distance and the Mahalanobis distance using the variance matrix, respectively, for $i l r$ coordinates. 


\section{CONCLUSION}

The critical nutrient approach is based on the assumption that nutrient interactions hidden in concentration values are negligible at high yield level, hence assuming no bias in the diagnosis of 'pure' nutrient concentration. However, since tissue analytical results are constrained to a closed compositional space, there must be resonance in the simplex even at high yield level due to composition varying within critical concentration ranges.

DRIS is a diagnostic tool that integrates dual ratio functions into nutrient indexes but the mathematical theory behind it is scanty. Nevertheless, some aspects of DRIS can be related to compositional data analysis through $\log$ transformations, especially the $c l r$ transformation. Still, the $c l r$ compounds all possible interactions into the geometric mean while some important interactions should be diagnosed separately.

The ilr coordinates provide sequential partitions of nutrient interactions arranged into an ad hoc interactive framework based on sound knowledge of nutrient classification, interactions, and management. The nutrient imbalance index is computed as the Aitchison distance between selected ilr coordinates of a given specimen and the standard ilr coordinates. The Mahalanobis distance can be computed but is very sensitive to location estimators. With progress still going in compositional analysis, the ilr concept appears to be the most appropriate to date for removing interaction-related biases that may spoil the diagnosis of nutrient imbalance in fruit crops.

\section{ACKOWLEDGEMENTS}

This project is supported by the Natural Sciences and Engineering Council of Canada (CRDPJ 385199 - 09). The author is grateful to Dr. SergeEtienne Parent for performing compositional analyses in the $\mathrm{R}$ package.

\section{REFERENCES}

AITCHISON, J. The statistical analysis of compositional data. London: Chapman and Hall, 1986. 416 p.

AITCHISON, J. The statistical analysis of compositional data (with discussion). Journal of the Royal Statistical Society Series B: Statistical Methodology, Oxford, v. 44, n. 2, p. 139-177, 1982.

BATES, T.E. Factors affecting critical nutrient concentrations in plants and their evaluation: a review. Soil Science, Baltimore, v. 112, p. 116-130, 1971.

BAYENS, J. Nutrition des plantes de culture. Louvain : Nauwelalaerts, Université de Louvain, 1967. $678 \mathrm{p}$.

BEAUFILS, E.R. Diagnosis and recommendation integrated system (DRIS). Pietermaritzburg: University of Natal, 1973. 132 p. (Soil Science Bulletin, 1)

BERGMANN, W. Ernährungs-störungen bei Kulturpflanzen. Stuttgart: Verlag Gustav Fischer, 1988. v.2, 762 p.

BEVERLY, R.B. Modified DRIS method for simplified nutrient diagnosis of 'Valencia' oranges. Journal of Plant Nutrition, New York, v. 10, p. 1401-1408, 1987a.

BEVERLY, R.B. Comparison of DRIS and alternative nutrient diagnostic methods for soybean. Journal of Plant Nutrition, New York, v. 10, p. 901-920, 1987b.

BHUPAL RAJ, G.; PRASAD RAO, A. Identification of yield-limiting nutrients in mango through DRIS indices. Communications in Soil Science and Plant Analysis, New York, v.37, n. 11-12, p. 1761-1774, 2006.

CALLOT, G. ; CHAMAYOU, H. ; MAERTENS, C. ; SALSAC, L. Mieux comprendre les interactions sol-racine: incidence sur la nutrition minérale. Paris: INRA, 1982. 325 p. 
EGOZCUE, J.J.; PAWLOWSKY-GLAHN, V. Simplicial geometry for compositional data. In : BUCCIANTI, A. ; MATEU-FIGUERAS, G. ; PAWLOWSKY-GLAHN, V. (Ed.). Compositional data analysis in the geosciences: from theory to practice. London: Geological Society, 2006. p. 145159. (Special Publication, 264)

EGOZCUE, J.J.; PAWLOWSKY-GLAHN, V. Groups of parts and their balances in compositional data analysis. Mathematical Geology, New York, v. 37 , p. 795-828, 2005.

EGOZCUE, J.J.; PAWLOWSKY-GLAHN, V.; MATEU-FIGUERAS, G.; BARCELÓ-VIDAL, C. Isometric logration transformations for compositional data analysis. Mathematical Geology, New York, v. 35 , p. 279-300, 2003.

ELWALI, A.M.O.; GASCHO, G.J. Soil testing, foliar analysis, and DRIS as guide for sugarcane fertilization. Agronomy Journal, Madison, v. 76, p. 466-470, 1984.

FILZMOSER, P; HRON, K. Outlier detection for compositional data using robust methods. Mathematical Geosciences, New York, v. 40, p. 243-248, 2008.

GIAMPIETRO, M. Multi-scale integrated analysis of agroecosystems. Boca Raton,: CRC Press, 2004. $437 \mathrm{p}$.

GÜSEWELL, S. N:P ratios in terrestrial plants: variation and functional significance. New Phytologist, Cambridge, v. 164, p. 243-266, 2004.

HADI, A. A modification of a method for the detection of outliers in multivariate samples. Journal of the Royal Statistical Society, Série B, Oxford, v.56, p. 393-396, 1994.

HADI, A. Identifying multiple outliers in multivariate data. Journal of the Royal Statistical Society, Serie B, Oxford, v.54, p. 761-771, 1992.

HALLMARK, W.B.; MOOY, C.J. de; PESEK, J. Comparison of two DRIS methods for diagnosing nutrient deficiencies. Journal of Fertilizer Issues, Manchester,v. 4, p. 151-158, 1987.
HERNANDEZ-CARABALLO, E.A.; RODRIGUEZ-RODRIGUEZ, O; RODRIGUEZ-PEREZ, $\mathrm{V}$. Evaluation of the Boltzmann equation as an alternative model in the selection of the high-yield subsample within the framework of the compositional nutrient diagnosis system. Environmental \& Experimental Botany, Elmsford, v. 64, n. 3, p. 225 231, 2008.

HOLLAND, D.A. The interpretation of leaf analysis. Journal of Horticultural Science. London, v. 41, p. 311-329, 1966

HUNDAL, H.S.; SINGH, D.; BRAR, J.S. Diagnosis and Recommendation Integrated System for Monitoring Nutrient Status of Mango Trees in Submountainous Area of Punjab, India. Communications in Soil Science and Plant Analysis, New York, v. 36, n. 15-16, p. 2085-2099, 2005.

JONES, W.W. Proposed modifications of the diagnosis and recommendation integrated system (DRIS) for interpreting plant analyses. Communications in Soil Science and Plant Analysis, New York, v. 12, p. $785-794,1981$

KENWORTHY, A.L. Leaf analysis as an aid in fertilizing orchards. In: WALSH, L.M.; BEATON, J.D. (Ed.). Soil testing and plant analysis. $5^{\text {th }} \mathrm{ed}$. Madison: Soil Soil Science Society of America, 1983. p.381-392.

KHIARI, L.; PARENT, L.E.; TREMBLAY, N. Selecting the high-yield subpopulation for diagnosing nutrient imbalance in crops. Agronomy Journal, Madison, v. 93, p. 802-808, 2001a.

KHIARI, L.; PARENT, L.E.; TREMBLAY, N. Critical compositional nutrient indexes for sweet corn at early growth stage. Agronomy Journal, Madison, v. 93, p. 809-814, 2001b.

KUMAR, P.S.S.; GEETHA, S.A.; SAVITHRI, P.; MAHENDRAN, P.P.; RAGUNATH, K.P. Evaluation of DRIS and CND indexes for effective nutrient management in Muscat grapevines (Vitis vinefera). Journal of Applied Horticulture, Lucknow, v. 5, n. 2, p. 76-80, 2003. 
LAGATU, H.; MAUME, L. The variations of the sum $\mathrm{N}+\mathrm{P} 205+\mathrm{K} 20$ per 100 parts of dry material of the leaf of a cultivated plant. Comptes Rendus de l'Académie D'Agriculture de France, Paris, v. 21, p. 85-92, 1935.

MALAVOLTA, E. Manual de nutrição de plantas. Piracicaba: Ceres, 2006. 631 p.

MARSCHNER, H. Mineral nutritionof higher plants. New York : Academic Press, 1986.674 p.

MARTIN-FERNANDEZ, J. A.; BARCELO-VIDAL, C.; PAWLOWSKY, V. Dealing with zeros and missing values in compositional data sets using nonparametric imputation. Mathematical Geology, New York, v. 35, p. 253-278, 2003.

MASSART, D.L.; VANDEGINSTE, B.G.M.; BUYDENS, L.M.C.; DE JONG, S.; LEWI, P.J.; SMEYERS-VERBEKE, J. Data handling and technology 20A: handbook of chemometrics and qualimetrics. New York: Elsevier, 1997. p1., 867 p.

MONTEIRO TERRA, M.; GERGOLETTI, I.F.; PIRES, E.J.P.; BOTELHO, R.V.; DOS SANTOS, W.R.; TECCHIO, M.A. Evaluation of the nutritional condition of Italia grapevine in the region of São Miguel Arcanjo-SP, using the diagnosis and recommendation integrated system. Revista Brasileira de Fruticultura, Jaboticabal, v. 29, n. 3, p. 710-716, 2007.

MOURÃO FILHO, F.D.A. DRIS and Sufficient Range Approaches in Nutritional Diagnosis of "Valencia" Sweet Orange on Three Rootstocks. Journal of Plant Nutrition, New York, v. 28, n. 4, p. 691-705, 2005.

MOURÃO FILHO, F.D.A. DRIS: concepts and applications on nutritional diagnosis in fruit crops. Scientia Agricultura, Piracicaba, v. 61, n. 5, p. 550-560, 2004.

NELSON, L. A.; ANDERSON, R. L. Partitioning of soil test-crop response probability . In: STELLY, M. (Ed.). Soil testing: correlating and interpreting the analytical results. Madison: American Society of Agronomy ,1984. p. 19-38. (Special Publication, 29).
ODEH, I.; TODD, A.J.; TRIANTAFILIS, J. Spatial prediction of soil particle-size fractions as compositional data. Soil Science, Baltimore, v.168, p.501$515,2003$.

PARENT, L.E., GRANGER, R.L. Derivation of DRIS Norms from a High Density Apple Orchard Established in Quebec Appalachians. Journal of the American Society of Horticultural Science, Alexandria, v. 114, n. 6, p. 915-919, 1989.

PARENT, L. E.; DAFIR, M. A theoretical concept of compositional nutrient diagnosis. Journal of American Society of Horticultural Science, Alexandria, v. 117, p. 239-242, 1992.

PARENT, L.E.; NATALE, W.; ZIADI, N. Compositional Nutrient Diagnosis of Corn using the Mahalanobis Distance as Nutrient Imbalance Index. Canadian Journal of Soil Science, Ottawa, v. 89, p. 383-390, 2009.

PARENT, L.E.; CAMBOURIS, A.N; MUHAWENIMANA, A. Multivariate diagnosis of nutrient imbalance in potato crops. Soil Science Society of America Journal, Madison, v. 58, p. 1432-1438, 1994.

PAWLOWSKY-GLAHN, V.; EGOZCUE, J.J. Compositional data and Simpson's paradox. Codawork . In: COMPOSITIONAL ANALYSIS WORKSHOP, 3., 2008. Girona, Disponível em: < http://dugi-doc. udg.edu/bitstream/10256/718/1/Pawlowsky Egozcue_SimpsonParadox.pdf $>$. Acesso em: $2 \overline{7}$ may 2008.

PAWLOWSKY-GLAHN, V.; EGOZCUE, J.J. Compositional data and their analysis: an introduction. In: BUCCIANTI, A., MATEU-FIGUERAS, G., PAWLOWSKY-GLAHN, V. (Ed.). Compositional data analysis in the geosciences: from theory to practice. London: Geological Society, 2006. p.1-10. (Special Publication, 264)

RAGHUPATHI, H.B.; REDDU, Y. T. N.; KURIAN REJU, M.; BHARGAVA, B.S. Diagnosis of Nutrient Imbalance in Mango by DRIS and PCAApproaches. Journal of Plant Nutrition, New York, v. 27, n. 7, p. $1131-1148,2005$. 
RIBEIRO NACHTIGALL, G.; DECHEN, A.R.. DRIS Use on Apple Orchard Nutritional Evaluation in Response to Potassium Fertilization. Communications in Soil Science and Plant Analysis, New York, v. 38, n. 17-18, p. 2557-2566, 2007.

RIGHETTI, T.L.; ALKOSHAB, O.; KRIS WILDER, $K$. Verifying critical values from DRIS norms in sweet cherry and hazelnut. Communications in Soil Science and Plant Analysis, New York, v. 19, n. 13, p. 1449-1466, 1988.

RODRIGUEZ, O.; ROJAS, E.; SUMNER, M. Valencia orange DRIS norms for Venezuela. Communications in Soil Science and Plant Analysis, New York, v. 28, n. 15-16, p. 1461-1468, 1997.

SANZ, M. Evaluation of interpretation of DRIS system during growing season of the peach tree: Comparison with DOP method. Communications in Soil Science and Plant Analysis, New York, v. 30, p. 1025-1036, 1999.

SHARMA, J.; SHIKHAMANY, S.D.; SINGH, R.K.; RAGHUPATHI, H.B. Diagnosis of Nutrient Imbalance in Thompson Seedless Grape Grafted on Dog Ridge Rootstock by DRIS. Communications in Soil Science and Plant Analysis, New York, v. 36, n. 19-20, p. 2823-2838, 2005.

SMITH, G.S.; BUWALDA, J.B.; CLARK, C.J. Nutrient dynamics in a kiwifruit ecosystem. Scientia Horticulturae, Amsterdan, v. 37, p. 87-109, 1988.
STUART-CHAPIN III, S. Ecological aspects of plant nutrition. Advances in Plant Nutrition, New York, v. 3, p. 161-191, 1989.

THOMAS, C.W.; AITCHISON, J. Log-ratios and geochemical discrimination of Scottish Dalradian limestones: a case study. In: BUCCIANTI, A., MATEU-FIGUERAS, G., PAWLOWSKY-GLAHN, V. (Ed.). Compositional data analysis in the geosciences: from theory to practice. London: Geological Society, 2006. p.25-41. (Special Publication, 264).

TRIONFO, A. The relative nutrient requirements of plants: optimizing nutrient ratios in mixed fertilizers. 2000. Disponível em: <http://www.netdor.com/ ernestm/AGRON2.HTM, 2000>.

UMESH, U.N.; PETERSON, R.A.; MCCANNNELSON, M.; VAIDYANATHAN, R. Type IV error in marketing research. The investigation of ANOVA interactions. Journal of the Academy of Marketing Science, Greenvale, v. 24, p. 17-26, 1996.

VRIES, O. DE. Ertragskurven, Ertragsgesetze und die Bedeutung der Gegenseitigen Beeinflussung der Wachstumsfaktoren. Zeitschritt für Pflanzenernährung und Bodenkunde, Weinheim, v. 14, p. $1-10,1939$.

WALWORTH, J.L.; SUMNER.M.E. The Diagnosis and Recommendation Integrated System (DRIS). Advances in Soil Science, New York, v. 6, p. 149$188,1987$. 